\title{
LANDSAT IMAGES ANALYSIS OF THE EXTENSION OF WATER VEGETATION ON THE BRĂDENI LAKES IN THE HÂRTIBACIU RIVER BASIN
}

\author{
Anita CONSTANTIN ${ }^{1}$
}

\begin{abstract}
Landsat images analysis of the extension of water vegetation on the Brădeni Lakes in the Hârtibaciu river basin. This study is part of a larger analysis of the changes of the cultural landscapes in the Hârtibaciu River Basin. Regarding the lacustrine landscape present in the village of Brădeni, we encounter massive changes in the landscape. The lakes were edified in the communist period with two main purposes: flooding prevention and pisciculture. In the last quarter-century the lakes administrations ignored the cleaning activities and the cutting of the water vegetation consisting mainly from reed and cattail, so that the lakes are at risk of full coverage with this species of plants. The progress of the degradation is analysed on different Landsat images. The conclusions suggest some solutions for an economic development with the harvesting of reed in concordance with the preservation of the species as part of Natura 2000 site.
\end{abstract}

Keywords: remote sensing imagery, NDVI, satellite images, spectral band combinations.

\section{INTRODUCTION}

The Brădeni lakes are located SE of the commune with the same name which lies in the Hârtibaciu Valley in the Sibiu county in Romania. The commune consists of three villages: Brădeni, Retiş and Țeline. Brădeni is located on the 106 county road, which makes the connection between Sibiu and Sighişoara. Brădeni lies at about $21 \mathrm{~km}$ from Agnita and about $22 \mathrm{~km}$ from Sighişoara. The population of 1541 inhabitants consist of Romanians, Gypsies and just a few Saxons and Hungarians. For many centuries with the exception of the communist period, the ground belonged to the private sector.

In communist period the state took over all the properties and mass agricultural production in the collective farm started. The construction of the lakes started in the flood plains on both sides of the Hârtibaciu river near the village Brădeni. The altitude of the valley near Brădeni is 480-475 m above sea level and the energy of the terrain is low. Therefore, the main occupation of the inhabitants was agriculture.

Due to the terrain morphology crops were often flooded during rainy periods and after snow melting. The high grade of humidity and the stagnation of water determined the authorities to build a fish farm.

The big project was initiated in 1954. On the construction site worked peasants with horses and oxen. The embankment was made out of braided willow branches and from the excavated soil.

1 "Babeş-Bolyai" University, Faculty of Geography, 400006 Cluj-Napoca, Romania, e-mail: anita.constantin@yahoo.com 


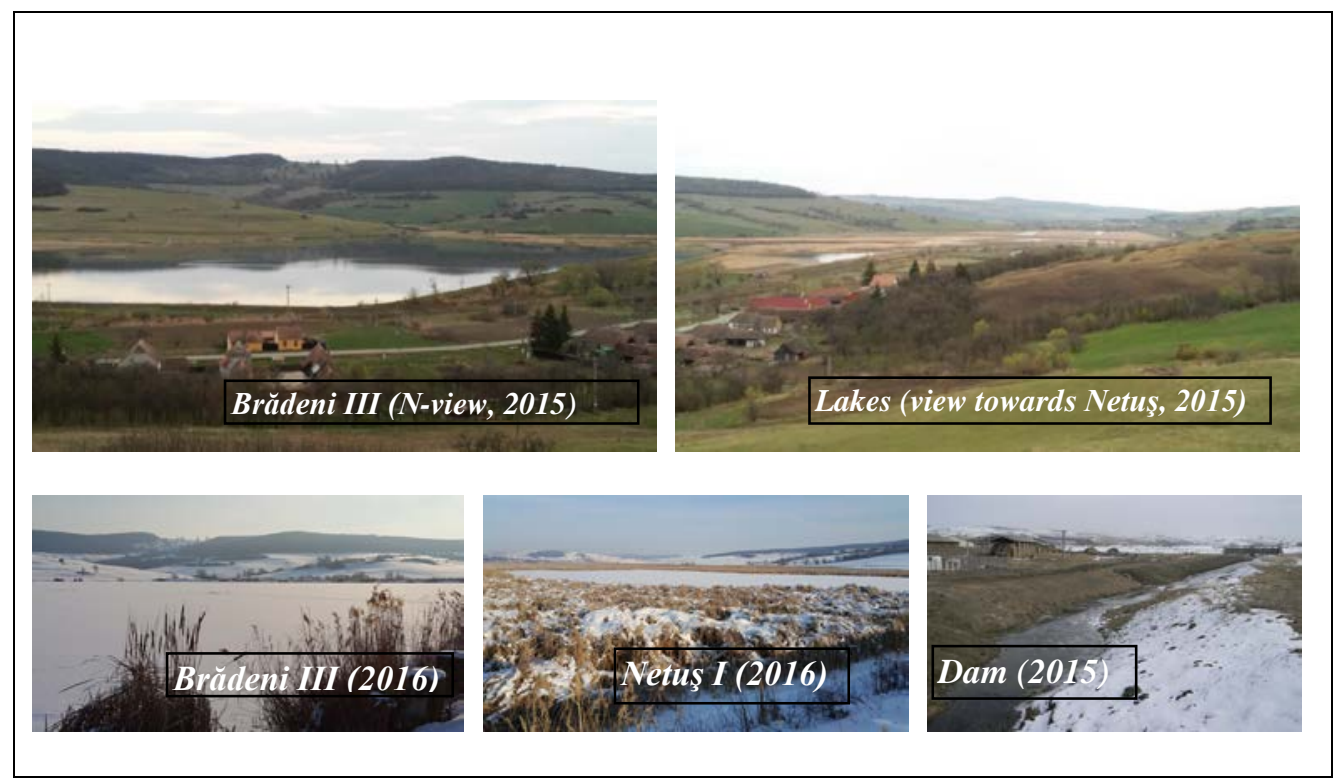

Fig. 1. Brădeni Lakes and Dam

Two big basins were made at the beginning. The water in the reservoirs was coming exclusively out of the Hârtibaciu River, because the river was flowing through the lakes. Through a connection system the basins were filled with water according to the principle of communicating vessels.

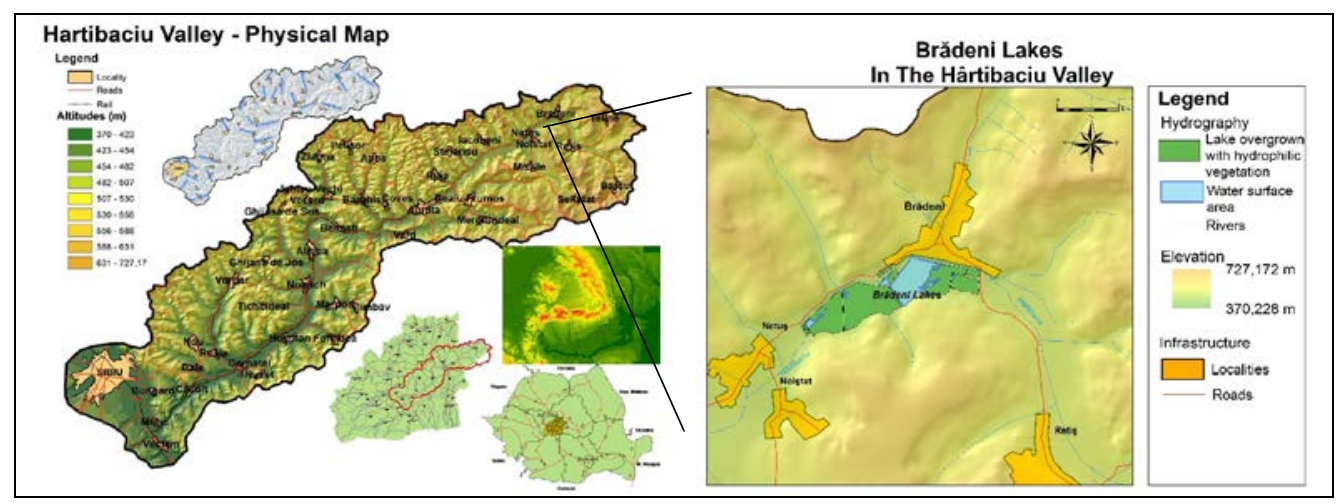

Fig. 2. Hârtibaciu Valley and the Brădeni Lakes

In the late 70's started a big project consisting of dividing the two initial basins and consolidating the embankments with concrete tiles against erosion. The consolidation was realized in 3 years. The water course of the Hârtibaciu River was changed and it was led in an artificial canal that surrounds the lakes following the road. Several pipes made the connection between the basins. The water reserve was assured through a pipe which collected water from the river surface. The newly built dam was financed by the commune hall and finished in 1985. The main 
purpose of the construction was prevention of flooding. The construction lies East of the village near the commune road 104D which connects Brădeni, Retiş and Bărcut, at about 150-200 m distance from the upstream basins.

The total surface of the farm was about 169.15 ha and the water reservoirs were divided as follows:

Table 1. Characteristics of the Brădeni Lakes

\begin{tabular}{|l|l|l|l|}
\hline Basin name & $\begin{array}{l}\text { Surface } \\
\text { (ha) }\end{array}$ & $\begin{array}{l}\text { Depth } \\
\text { (m) }\end{array}$ & $\begin{array}{l}\text { Water } \\
\text { volume (CM) }\end{array}$ \\
\hline Lake I Netuş & 28 & 1.5 & 504000 \\
\hline Lake II Netuş & 45 & 1.8 & 810000 \\
\hline Lake III Brădeni & 54 & 1.9 & 1026000 \\
\hline Pond IV Brădeni & 4 & 1.5 & 60000 \\
\hline Pond V Brădeni & 2 & 1.5 & 30000 \\
\hline Pond VI Brădeni & 12 & 1.6 & 192000 \\
\hline $\begin{array}{l}\text { Basins Brădeni 1-3 (for } \\
\text { temporary stocking, } \\
\text { reproduction, wintering) }\end{array}$ & 1 & 1.1 & 11000 \\
\hline $\begin{array}{l}\text { Basins - Netuş 1-5 (for } \\
\text { temporary stocking, } \\
\text { reproduction, wintering) }\end{array}$ & 1.5 & 1.8 & 27000 \\
\hline Total & $\mathbf{1 4 7 . 5}$ ha & $\begin{array}{l}\text { Average } \\
\mathbf{1 . 5 8 ~ m}\end{array}$ & $\mathbf{2 6 6 0 0 0 0 ~ c m}$ \\
\hline
\end{tabular}

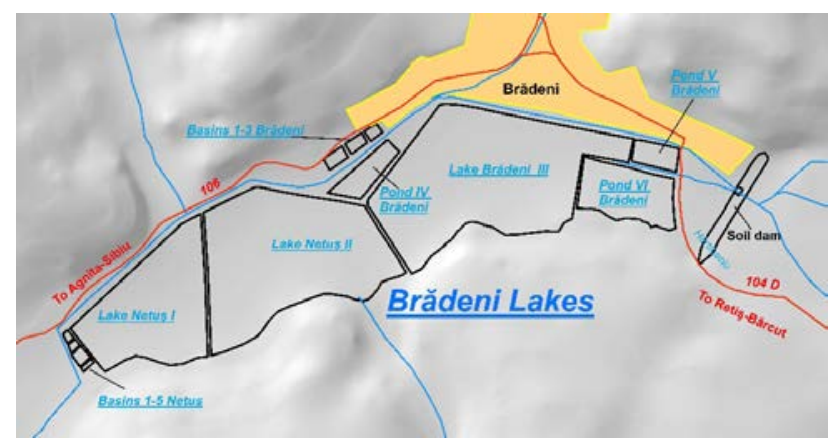

The depth of the water in the lakes was at about $2,20 \mathrm{~m}$ in years with rich precipitations. In the small basins water had a depth of $80 \mathrm{~cm}-1 \mathrm{~m}$. The fry in quantity of $30-35$ tons were brought from other fish farms in the country, like Piscicola Timişoara, Timiş county, Piscicola Ineu, Arad county or from Zau de Câmpie, Mureș county. The Silver Carp fry was brought from Nucet, Dâmboviţa county, where is one of the biggest research and development centers for pisciculture in Romania. The fry was brought in big plastic bags filled with water. The age at the transportation was 5 to 6 days and they were the size of a pin.

Fig. 3. Plan of Brădeni Lakes

The fry was dropped in the basins and after 3-4 weeks started the feeding with flour on the water surface. Also the farm in Brădeni proceeded in having a reproduction, both artificial and natural. Downstream towards Netuş on an area of 1,5 ha 5 basins were used for reproduction, temporary stocking and wintering. Also upstream towards Retiş two ponds of 2 ha and 4 ha were used for the reproduction of Carp (Cyprinus carpio) and Silver carp (Hypophthalmichtys molitrix). Other 3 basins with an area of 1 ha situated near the main entrance were used for reproduction and 1 pond of 4 ha for depositing the fish. The two species had different eating and growing pace. The Silver Carp unlike the Carp exceeded in consuming food prepared out of the sun flower residue, flax, wheat and yeast from May to September; in July and August also corn was supplemented for growing and gaining weight. The Silver Carp had a good production and the sales were 
growing. People liked its tender meat over the drier one of the Carp. The mass fishing was made from August till freezing time. The highest production was about $180 \mathrm{t}$ in 1975 but on average the sales were at about $150 \mathrm{t}$ /annual.

The two main districts where the fish was sold were Sibiu and Mureş. In winter time the employees were cutting $2 \mathrm{~m}^{2}$ holes in the ice for respiration and aeration. Also in winter time people used to scythe the cattail (Typha sp.) and reed (Phragmites australis) plants from the ice. Harvesting these plants also happened in the fall when people from Harghita and Covasna counties came and were taking it for free to use it for braiding baskets and carpets. The plants were harvested by the people going into the water with high boots and were dried on the embankment in sheaves.

Since founding in 1954 the lakes were administrated by the Gostat Brădeni, a state sector responsible for agriculture. Starting with 1970 the farm was administrated by the company Piscicola Cluj and from 1973 till 1983 by the pisciculture farm in Zau de Câmpie. Short before 1989 it was administrated by the Piscicola Sibiu company and then it was dissolved and founded as a share company in 1991. Three associates took it over until 2004 when the company Ficova Com S.R.L. resumed. The firm is registered in Sighişoara, in Mureş county and according to its owner, he bought the basins in 2005. Since then the reservoirs have been used only for sport fishing. A few years after taking over the new owners still brought fry from other farms and fed them to grow and gain weight. Nowadays they leave the fish to breed naturally. They gave up bringing fry and feeding them. Nor made they any investments.

Today the former buildings of the offices, the cottages, the barns look like they've been abandoned. The reservoirs are in a bad state and condition. The vegetation overgrew the water surface of the lakes starting at the tail of the lakes where the depth was the lowest, so that in a few years it will cover up the whole water surface. The lake Netuş II has been totally compromised, Netuş I is also almost covered up with vegetation and Brădeni III lake is at its half. Some of the basins,

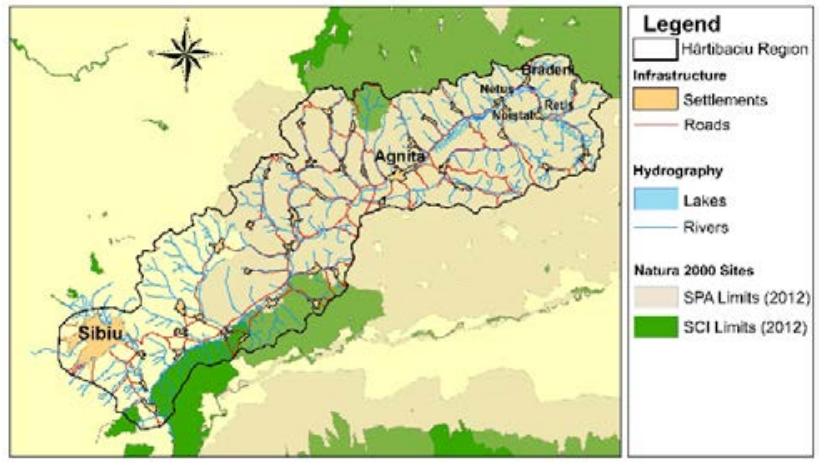

Fig. 4. Natural protected areas in the Hârtibaciu Valley especially those upstream, haven't been used at all and are covered totally with vegetation. The nature conquered its initial space and besides the two main species of cattail and reed, which invaded the reservoirs, we encounter other species of hydrophilic plants like algae, willows, bulrush etc.

Also, many species of birds have found their temporary home here: storks, ducks, herons, gulls, coots, egrets, swans, geese etc. Not only small fish but also insects, lizards and frogs serve as their food. Although very dangerous because of the water freezing over, some of the birds, ducks and coots, spend the winter in the reed 
thickets. At one glimpse one would think to be in the delta of a river. As a protection for these avian species and not only, the administration was informed by the Environment Ministry that the whole area of the Brădeni lakes will be also included in the protected area Natura 2000 site, registered with the number ROSPA0099. Starting with 2007 the valleys of Hârtibaciu and Târnava Mare are natural protected areas for their over 60 jeopardized species from extinction. For the administration of the Brădeni lakes no special protection measures for the birds were imposed.

\section{ANALYSIS OF LANDSAT SATELLITE IMAGES}

The extension of the reed vegetation can be analysed on different aerial images. These images were taken by US Landsat satellites starting with 1972 and until present time were a number of 8 Landsat missions. With each launched satellite the quality of the images improved. The satellite images can be described as spectral, spatial, temporal and radiometric. They are taken in multispectral bands, where each band has a different wavelength and resolution. Combining different bands can highlight different features of the terrain.

The image of the surface is captured at a certain resolution. If Landsat-1 had a resolution of $80 \mathrm{~m}$, the latest Landsat 8 can shoot images at a resolution of $15 \mathrm{~m}$. The latest satellites (Ikonos, GeoEye, QuickBird, World View etc.) can offer even more precise images than that and increasingly more data becomes open for the public. On their orbits the satellites are revisiting in certain temporal intervals the same area. This can be from 3 to 18 days repeating cycle to full global coverage depending on the satellite mission, model and purpose. The biggest online archive of satellite images is available at http://glovis.usgs.gov/ (USGS - the Science Agency for the Department of the Interior of the United States).

The images used for this study are not taken at equidistant periods of time. The first available Landsat image for the Brădeni Lakes area of study is dated on the $29^{\text {th }}$ of July 1973 . Considering the cloud coverage or clarity, the images which were representative are presented in the following comparison. The most relevant images to be compared are taken in the following years: 1982, 2005, 2016. The satellite images are identified on path 198 and the row 28.

\section{METHODOLOGY IN THE COMPARISON}

The used software was ArcMap 10.1. Both a cartographic material 1:25 000 and the downloaded 2016's satellite image of the Brădeni Lakes were digitized and kept as base maps. The Landsat images necessary for the comparison were downloaded from the archive of the USGS. The older data (Landsat 1-3) came as a multispectral image in jpeg or tiff format.

The first images took into consideration were those starting from 1982. Older ones are not very conclusive because of the poor resolution and the bigger pixel size. The later images were taken by more proficient satellite sensors and these came in separate bands. In this case the image analysis function in ArcMap was used to create a composite image. 


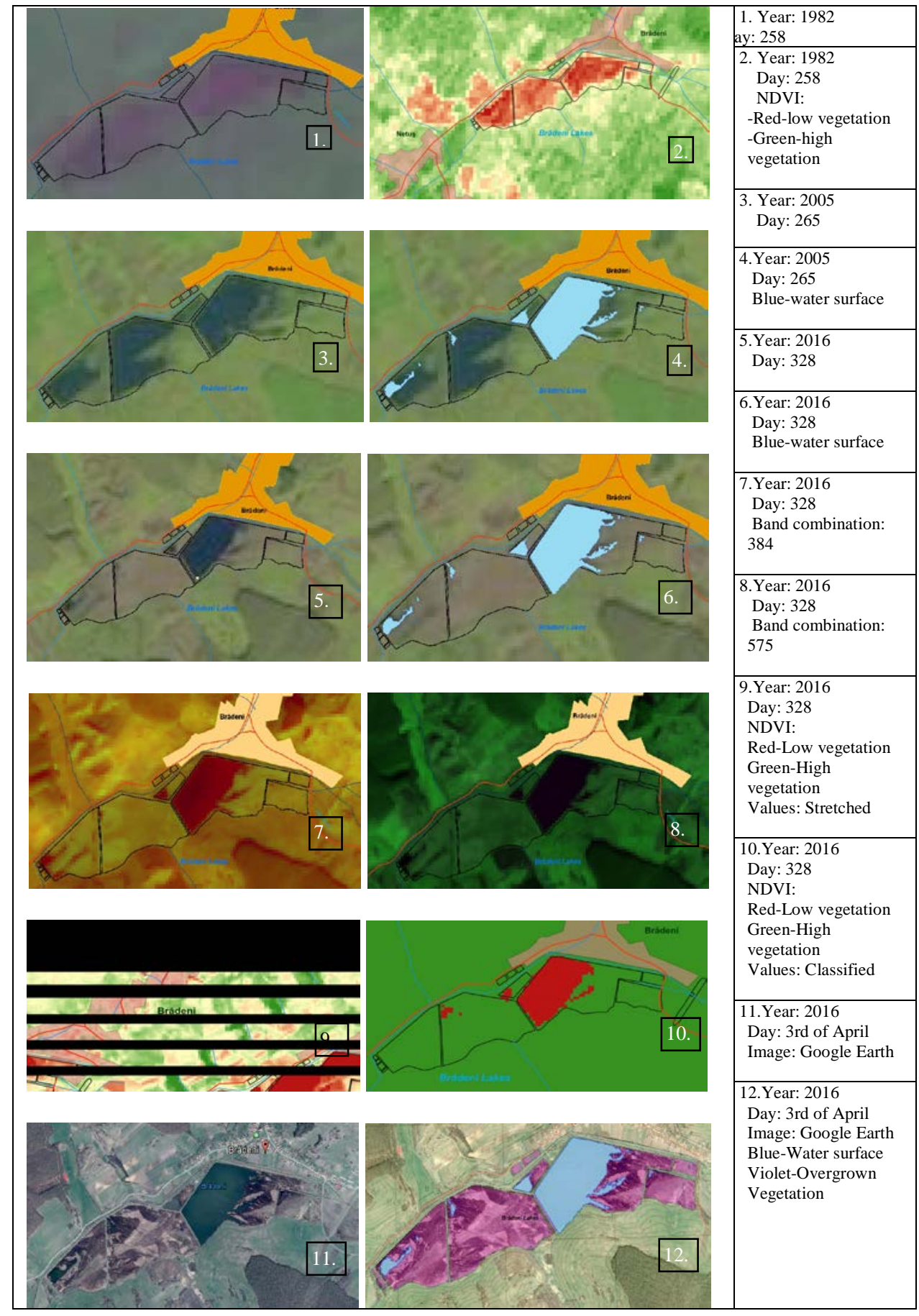

Fig. 5. Increasing vegetation and decreasing water surface compared on Landsat images 
The images needed a correction of the position, which was adjusted with the georeferencing tool. The composite image was created as a layer and analysed after overlapping the layer of today's water surface. This shape file was digitized after the 2016 CNES/Astrium satellite image downloaded from Google Earth Pro at the maximum resolution of $4800 \times 2487$ (4K) which has been also georeferenced. The image was taken on the $3^{\text {rd }}$ of April, altitude of sight was $3,53 \mathrm{~km}$ and the altitude was $472 \mathrm{~m}$ above sea level. In the comparison it is presented at the end of the images series with the addition of violet color. The contrast offers a better observation of the vegetation coverage of the Brădeni Lakes (Fig. 5).

For the satellite images from 2016 different band combinations are shown. These band combinations reveal more enhanced the colour difference between the water surface of the lakes and the surface covered by vegetation. The combination of the bands was realized using the symbology tool of each layer changing the order of the overlapping multispectral bands.

The pairs of images shown in figure 5 are put aside. The first two images are from 1982, day 258. In the image on the right side the bands are combined in natural view 321 and the one on the left shows the NDVI image. The surface of the water is in red, which means that there is low vegetation. The NDVI is the Normalized Difference Vegetation Index. Healthy vegetation (or chlorophyll) reflects more near-infrared (NIR) and green light compared to other wavelengths. It absorbs more red and blue light. NDVI maps use NIR and red channels to measure of healthy vegetation. The formula of NDVI $=($ NIR-red $):(\mathrm{NIR}+\mathrm{red})$. The values of the index are calculated from -1 to 1 .

The images 3 and 4 in figure 5 are taken in 2005, day 265. The bands are combined in natural view 321 and in addition image 4 has a layer with today's water surface of the lakes. From previous 2 pictures an extension of the vegetation area can be observed. The images 5 and 6 taken in 2016, day 328, are also in natural view 321 combination with the water surface added to picture 6 . Recognizing by the colour of the pixels, the vegetation coverage is almost complete on Netuş I and II Lakes. Picture 7 and 8, taken in 2016, day 328, show different band combinations, 384 and 575, which reveal very relevant colours of the pixels. Images number 9 and 10 show in two ways the calculation of the NDVI: in picture 9 the representation of the index is displayed with the stretched function and in picture 10 the same attributes are shown as classified. It is very conclusive how the red colour pixels correspond to the not overgrown water surface of the lakes. The last two images 11 and 12 are downloaded from Google Earth Pro and are images taken on the $3^{\text {rd }}$ of April 2016. For a better contrast in image 12 two layers are added to the original satellite image. The water surface is displayed in light blue and the vegetation area is enhanced with a violet colour tone.

Thinking back at the construction of the lakes, when no vegetation at all existed, the fish farm had the maximum yield. The administrators throughout the past decades didn't concern enough for maintaining the lakes and ponds in good condition. Starting already in communist period before 1989 the employees didn't cut the vegetation in the reservoirs. The low quantities which were harvested in a few years by the basket and rugs manufacturers were insignificant for the invasive growth and extension of the vegetation. 
In 1991 after the farm went from the state into the private sector the situation only got worse, as it can be seen today. The compromised reservoirs are less usable for the fishery's purposes, but as a habitat for the birds. If no ameliorative measures will be taken in the near future Netuş I Lake and the biggest lake, Brădeni III will be also overgrown with vegetation. Not even sport fishing will be possible and the once profitable big fish farm is going down for good. Neglecting the cleaning jobs and not modernizing the farm will destroy the entire farm.

\section{CONCLUSIONS}

Drastic measures of cutting the vegetation should start immediately. Cutting the reeds and cattail plants will not only bring a free resource for the locals, but will also not endanger the fish life by taking all the oxygen from the water. The administrator could use the help of the population which lacks of jobs. A braiding specialist could be brought to teach the locals how to make different products from reed and cattail as slippers, rugs, baskets, hats, door and other mats, fences, isolation mats for roofing, boxes or other decoration objects.

Together with a biologist from the Environment Ministry offices in Sibiu an inventory of the birds should be made. One or two of the ponds for example 5 and/or 6 Brădeni could be declared strictly protected areas in order to become a safe habitat for every year nesting birds. From these ponds harvesting the plants should be made only as special measures to maintain a good and propitious habitat for the birds. As a plan for modernising the farm could be the founding of a reproduction centre for indigenous carp fry. If the profit rates are increasing, also some lacustrine lodges for tourists could be built. Exploiting the big potential that the Brădeni Lakes have, could be the subject of a future research.

\section{REFERENCES}

1. Grecu Florina (1992), Bazinul Hârtibaciului.Elemente de morfohidrografie, Ed. Academiei Române, Bucureşti

2. Nistor, M. M., Using Landsat Images and GIS to Assess the Changes of Mer de Glace and Marmolada Glaciers, in the Last Three Decades, Studia UBB Geographia, LIX, 1, 2014, pp. $65-76$

3. Visan Livia, Abdellaoui, A., Patru-Stupariu, Ileana, (2012), Analyse du paysage par traitement des images satellitales: cas du versant oriental des monts Bucegi (Roumanie), Analele Universităţii „Spiru Haret”, Seria Geografie, Nr. 15, P.21, Ed. Fundaţiei „România de maine”

4. *** (2010), Planificarea şi amenajarea teritoriului zonal, Studiu de caz: Valea Hârtibaciului, Presa Universitară Clujană, Cluj-Napoca

5. ***(2005), Bilanţ de mediu pentru ferma piscicolă Brădeni-SC Piscicola SA Sibiu

6. http://www.mdrap.ro/userfiles/patz_valea_hartibaciului_raport_mediu.pdf

7. http://www.mmediu.ro/beta/domenii/protectia-naturii-2/arii-naturale-protejate/

8. http://glovis.usgs.gov/

9. http://biodiversitate.mmediu.ro/rio/natura2000/view?doc_id=ROSPA0099

10. http://earthobservatory.nasa.gov/Features/MeasuringVegetation/

11. https://pubs.usgs.gov/pp/p1386a/gallery2-fig75.html

12. https://landsat.usgs.gov/what-are-band-designations-landsat-satellites 